\title{
Pendampingan Milennial Peer Counselor (MPC) Melalui Konseling Realitas Dalam Meneguhkan Karakter Santri Di Pondok Nurul Jannah Kudus
}

\author{
Khilman Rofi’ Azmi, Dwi Ima Herminingsih \\ Institut Agama Islam Negeri (IAIN) Kudus, Universitas Tulungagung \\ rofiazmi@iainkudus.ac.id,dwima.hermin@gmail.com
}

\begin{abstract}
The purpose of community service (PKlM) with the format of Millennial Peer Counselor (MPC) through reality counseling at Islamic Boarding School (Pondok Pesantren) Nurul Jannah, Kudus are as follow (1) provides insight into the importance of counseling services and the process of providing assistance to the needy; (2) equip the students of Islamic Boarding School (santri) with Reality counseling skills in finding alternative solutions for the ones who want to consult; (3) generate the peer counselor agents so that students can be referrals to friends. Soon after the program finished Santri has a special ambassador or cadre who will share and work together to solve their daily psychological problems. The results of community service include (a) Santri get insight about communication techniques and counseling that can be provided as peer counselors; (b) Institutions can map psychological problems in order to improve the quality of learning and social in Islamic Boarding School; (c) Through Millenial Peer Counselor, institutions are able to establish special bureaus or special units related to various psychological services aimed at students such as Islamic Counseling Centers, and (d) institutions have a broader opportunity to develop students with additional competencies to millennial peer counselor ambassadors such as Muslim motivator, young instructors, and self-development trainers for fellow students and the environment around the cottage.
\end{abstract}

Keywords: Millennial Peer Counselor (MPC); Islamic Boarding School

\begin{abstract}
Abstrak
Tujuan pengabdian kepada masyarakat (PKIM) dengan format pendampingan Milenial Peer Counselor (MPC) melalui konseling realitas di Pondok Pesantren Nurul Jannah, Kudus antara lain (1) memberikan wawasan tentang pentingnya layanan konseling dan proses pemberian bantuan kepada yang membutuhkan; (2) membekali santri dengan keterampilan konseling Realitas dalam menemukan alternatif solusi bagi konselinya; (3) mencetak agenagen konselor sebaya agar para santri dapat menjadi rujukan teman curhat. Hal tersebut sesuai dengan hasil yang didapatkan setelah kegiatan pengabdian dilaksanakan yakni Santri memiliki duta atau kader khusus yang dapat menjadi rujukan mereka dalam menyelesaikan masalah sehari-hari (Daily Problem) terutama yang bersifat psikologis. Hasil pelaksanaan pengabdian kepada masyarakat antara lain (a) Santri memperoleh wawasan tentang teknik komunikasi dan konseling yang dapat menjadi bekal menjadi konselor sebaya; (b) Lembaga dapat melakukan pemetaan terhadap permasalahan psikologis santri demi meningkatkan kualitas pembelajaran dan sosial di pesantren; (c) Melalui Millenial Peer Counselor lembaga
\end{abstract}


mampu mendirikan biro khusus atau unit khusus berkaitan dengan berbagai layanan psikologis yang ditujukan untuk santri seperti Pusat Konseling Islam, dan (d) Lembaga mempunyai kesempatan yang lebih luas untuk mengembangkan santri dengan kompetensi tambahan kepada duta konselor sebaya milenial seperti kompetensi motivator muslim, instruktur muda, dan trainer pengembangan diri bagi sesama santri dan lingkungan sekitar pondok.

Kata Kunci: Pendampingan; Millenial Peer Counselor (MPC); Pesantren

\section{A. PENDAHULUAN}

Cepatnya perkembangan teknologi dan informasi di era Postglobalisasi telah memberikan dampak yang signifikan bagi dunia pendidikan Islam. Dampak tersebut terbagi menjadi dua jenis yakni dampak positif dan negatif. Dampak atau Effect positif adalah semakin mudahnya akses informasi melalui gadget atau gawai canggih sehingga dapat membantu persoalan kehidupan, selain itu melalui perkembangan tersebut juga memberikan kesempatan seluas-luasnya bagi seseorang untuk semakin mengembangkan seluruh kreativitas demi melahirkan karya-karya monumental (Azmi, 2018). Namun demikian, disisi lain efek negatif dari fenomena cepatnya arus informasi dan teknologi ialah semakin meningkatnya angka kekerasan dan kenakalan pada usia Milenial yakni remaja hingga dewasa awal. Contoh perilaku seperti Bullying, tawuran, pergaulan bebas, kecanduan dan penyalahgunaan obat terlarang merupakan indikator permasalahan utama yang harus diatasi terutama oleh hadirnya pendidikan Islam dalam setting Pondok Pesantren.

Pondok Pesantren sebagai salah satu lembaga pendidikan tertua di Indonesia diharapkan mampu berkembang sesuai dengan tuntutan zaman dengan tanpa meninggalkan nilai-nilai Islam dan budaya(Rahmi, 2001). Pada setting pendidikan seperti sekolah dan pesantren, selain peran dari Kyai, Ustadzahatau guru, kepala sekolah, tenaga kependidikan dan seluruh warga sekolah, peran dan posisi Konselor juga dianggap sentral dan menjadi sorotan dalam menangani permasalahan khususnya bagi santri(ABKIN, 2008). Disisi lain, konsep Bimbingan dan Konseling telah dikenal di Indonesia sebagai salah satu fasilitasi layanan guna menunjang pencapaian tugas perkembangan serta penyelesaian berbagai permasalahan remaja hingga usia dewasa awal(Fenti Hikmawati, 2015).

Bimbingan dan konseling merupakan terjemahan dari istilah Guidance \& Counseling dalam Bahasa Inggris. Sesuai dengan istilahnya, maka bimbingan dapat diartikan secara umum sebagai suatu bantuan (Santoso, 2008). Sebagai suatu concept bimbingan dapat diartikan sebagai bantuan kepada seseorang (individu), sebagai construct pendidikan, bimbingan adalah melengkapi pengalaman siswa untuk memahami dirinya, dan sebagai program pendidikan, bimbingan adalah prosedur dan proses yang diorganisir untuk mencapai tujuan pendidikan dan pribadi secara nyata (Shertzer, Bruce \& Stone, n.d.). Sedangkan istilah konseling merupakan salah satu jenis teknik pelayanan bimbingan di antara pelayanan-pelayanan lainnya, dan sering dikatakan sebagai inti dari keseluruhan pelayanan bimbingan. (Schmuller., n.d.) mengatakan bahwa: Counseling is the heart of guidance program. Selanjutnya dikatakan pula bahwa: Guidance is breader; counseling is a most important tool of guidance. Bimbingan itu lebih luas, dan penyuluhan merupakan alat yang paling penting dari usaha pelayanan bimbingan. Bahkan (M.H., n.d.) menyatakan 
counseling is the heart of the guidance program, konseling adalah jantung hatinya program bimbingan.

Dominannya orang dewasa dalam berkomunikasi dengan kalangan remaja dapat menjadi sebuah hambatan atau obstacles bagi penyelesaian masalah santri. Dalam kajian keilmuan Psikologi dan Konseling, santri yang notabene menjalani usia remaja membutuhkan banyak dukungan dan pihak yang dapat dipercaya serta "nyambung" dalam diajak berkomunikasi berkaitan dengan masalah-masalah yang sedang dihadapinya (Hurley, Pfadt, ..., \& 1996, n.d.). Santri usia remaja hingga dewasa awal memiliki ikatan yang kuat dengan lingkungan sebayanya sehingga sering disebut dengan siginificantothers. Banyak pihak yang kurang memahami jika santri tunduk dan tidak ada masalah berarti di pesantren maka hal tersebut dimaknai bahwa santri-santri tersebut sudah bahagia dan sehat secara mental psikologis, padahal kenyatannya belum tentu. Sebagian besar santri merasa harus memendam dan meredam segala bentuk permasalahan bagi dirinya, terkadang mereka juga menceritakan kepada teman-temannya, namun tidak semua teman dapat memberikan intervensi jalan keluar yang baik. Oleh karena itu, konselor sebaya merupakan salah satu alternatif solusi dalam rangka mempersiapkan santri memiliki wawasan dan keterampilan dalam membantu temannya yang sedang bermasalah. Konselor sebaya merupakan istilah yang disematkan pada beberapa kader konselor muda untuk diberikan kewenangan membantu temannya melalui layanan konseling setelah lulus pelatihan konselor sebaya atau sejenisnya.

Konselor sebaya merupakan salah satu istilah dalam kajian keilmuan konseling berkaitan dengan pemberian layanan bantuan oleh seorang konselor kepada teman sebaya yang membutuhkan. Istilah konselor sebaya juga mengacu pada pengertian dari (Carter \& Janzen, 1994) yang mengatakan "Peer counseling is a process by which one person is helped by another who has had similar or related experiences". Berdasarkan keterangan tersebut dapat dimaknai bahwa konseling sebaya adalah proses bantuan yang dilakukan oleh seorang kepada konseli yang memiliki pengalaman mirip atau relevan.

Salah satu Organisasi Penelitian komunitas bernama Research Utilizing Community (2009) menunjukkan urgensi konselor sebaya sebagai "Professionals in a variety of helping fields recognize and utilize peer counseling as a very effective resource" yang artinya para pekerja profesional dalam kategori helping profession mengenali dan membutuhkan konseling sebaya sebagai sumberdaya yang sangat efektif dalam mensukseskan program layanan mereka. Berdasarkan beberapa keterangan tersebut, dapat disimpulkan bahwa munculnya layanan konseling sebaya sangat penting dan efektif dalam menanangi permasalahan di lapangan.

Konseling sebaya di pesantren merupakan salah satu fenomena yang menjadi indikator perkembangan keilmuan konseling secara pesat. Namun demikian, berbagai bentuk pelatihan dan seminar tentang konseling sebaya masih jarang dilakukan di pesantren. Penelitian yang dilakukan oleh (Hotifah, 2017) menunjukkan bahwa pesantren sebagai lembaga pendidikan dan pengembangan karakter membutuhkan pelatihan dan pendampingan konselor sebaya. Oleh karena itu, ketika proses pendampingan konseling sebaya dilakukan dengan baik, maka hasilnya sangat signifikan dan meminimalisir berbagai permasalahan santri.

Peranan konselor muda/ sebaya kaitannya dengan tujuan bimbingan dan konseling merupakan usaha membantu peserta didik dalam pengembangan 
kehidupan pribadi, kehidupan sosial, kegiatan belajar, serta perencanaan dan pengembangan karier. Pelayanan konseling memfasilitasi pengembangan peserta didik secara individual, kelompok dan/atau klasikal, sesuai dengan kebutuhan, potensi, bakat, minat, perkembangan, kondisi, serta peluang-peluang yang dimiliki. Pelayanan ini juga membantu mengatasi kelemahan dan hambatan serta masalah yang dihadapi peserta didik (Fenti Hikmawati, 2015).

MPC atau Milennial Peer Counselor merupakan salah satu upaya dalam rangka menciptakan kader-kader muda konselor sebaya usia milenial yang dapat diberdayakan untuk membantu dalam menangani permasalahan-permasalahan psikologis santri Pondok Pesantren Nurul Jannah Kudus melalui pendampingan dan pelatihan Konselor Sebaya Milenial. Pendekatan dan teknik konseling Realitas dipilih dengan pertimbangan mudah dan cepatnya teknik ini untuk digunakan dalam menganalisis suatu permasalahan serta menggunakan pendekatan yag sesuai nilainilai dan prinsip Islam. Pendekatan Konseling Realitas didasarkan pada pemilihan keputusan terbaik dalam setiap langkah kehidupan sehingga cocok dengan keadaan santri yang merasa cemas, stres, jenuh, galau dan permasalahan psikologis lainnya. Konselor sebaya Islam di pesantren merupakan salah satu wujud nyata kepedulian dalam meningkatkan kondisi psikologis santri sehingga santri dapat berkembang secara optimal sesuai dengan bakat dan minat mereka sesuai dengan nilai-nilai dan prinsip Islam.

\section{B. PELAKSANAAN DAN METODE}

Pelaksanaan Kegiatan Pengabdian kepada Masyarakat Pendampingan Millenial Peer Counselor melalui konseling realitas di Pondok Pesantren Nurul Jannah, Kudus berikut menggunakan beberapa tahapan yakni :

Pertama, merencanakan. Kegiatan merencanakan mencakup merancang dan merencanakan survei kebutuhan atau need assessment berkaitan dengan layanan bimbingan dan konseling; mengolah hasil survei tersebut menjadi kerangka acuan pola pendampingan yang menjadi dasar perumusan materi serta tujuan bimbingan dan konseling; serta menerjemahkan kerangka acuan tersebut menjadi panduan layanan bimbingan dan konseling yang berisi rincian materi dan tujuan bimbingan, pedoman pelaksanaan, proses serta urutan kegiatan serta desain peralatan dan media yang akan digunakan.

Kedua, merancang jadwal kegiatan dan persiapan teknis yang dibutuhkan. Kegiatan ini merupakan salah satu kegiatan yang penting karena merancang jadwal membutuhkan koordinasi aktif dengan pimpinan lembaga sehingga berakhir pada kesepakatan waktu penyelenggaraan. Hal ini dibutuhkan karena kegiatan santri yang cukup padat di pesantren ini. Selanjutnya adalah persiapan teknis yang membutuhkan ketelitian dalam melengkapi daftar keperluan teknis yang dibutuhkan pada saat kegiatan berlangsung.

Ketiga, melaksanakan kegiatan yakni memfasilitasi proses secara bertahap. Fasilitasi akan dilaksanakan oleh tim dengan narasumber yang telah berkompeten dan memiliki kualifikasi khusus sehingga santri akan mendapatkan materi secara lebih komprehensif. Kegiatan fasilitasi menggunakan model seperti workshop dan pelatihan yang berbasis pada pemecahaan masalah melalui layanan konseling 
dengan pendekatan realita terapi. Setelah kegiatan tersbeut selesai maka dilakukan review dan refleksi untuk memberikan pendalaman bagi peserta pendampingan.

Keempat, mengendalikan yakni mengamati jalannya semua proses kegiatan. Tim melakukan observasi dengan tujuan memastikan kegiatan dapat berlangsung dengan baik sesuai dengan rencana awal. Monitoring juga dilakukan dalam rangka memastikan proses yang berlangsung di pondok pesantren tersebut dapat berjalan dengan baik serta mendapatkan progres yang dibutuhkan. Jika terdapat hambatan dalam proses pengendalian ini, maka tim akan segera bertemu untuk melakukan musyawarah singkat demi menemukan alternatif solusi yang paling tepat untuk menangani hambatan tersebut.

Kelima, melakukan evaluasi (Sukmadinata., 2012) yaitu menginventarisir berbagai permasalahan yang muncul selama proses penyelenggaraan. Evaluasi total digunakan demi melihat secara lebih detail proses pelaksanaan kegiatan ini. Jika terdapat hambatan yang mempunyai konsekuensi terhadap pelaksanaan kegiatan, maka akan dilakukan perbaikan sehingga tidak terjadi atau muncul kembali pada pertemuan-pertemuan kemudian. Tahapan tiap kegiatan pelaksanaan dapat dilihat dari Tabel 1 berikut:

\begin{tabular}{|c|c|c|c|c|c|}
\hline \multirow{2}{*}{ No } & \multirow{2}{*}{ Kegiatan } & \multicolumn{4}{|c|}{ Bulan } \\
\hline & & Agustus & September & Oktober & November \\
\hline 1 & $\begin{array}{l}\text { Pengabdian dan Penggalian } \\
\text { Data }\end{array}$ & $\sqrt{ }$ & $\sqrt{ }$ & $\sqrt{ }$ & \\
\hline 2 & Penulisan Laporan & & & & $\sqrt{ }$ \\
\hline 3 & PenyerahanLaporan Akhir & & & & $\sqrt{ }$ \\
\hline
\end{tabular}

\section{HASIL DAN PEMBAHASAN}

Pondok Pesantren Nurul Jannah bertempat di Desa Ngembalrejo RT 05 RW 04 Kecamatan Bae, Kabupaten Kudus. Pertama kali dirintis oleh K.H. Ahmad Zaenuri dengan pola awal komunitas pengajian hingga kini telah berkembang dengan pesat. Kondisi dampingan saat ini berkaitan dengan adanya program konselor sebaya adalah belum diselenggarakan secara aktif, namun demikian lembaga pesantren memiliki beberapa ustadz / ustdazah yang selama ini memberikan monitoring kepada santri termasuk ketika pendampingan terhadap masalah-masalah psikologis yang dialami oleh santri seperti kejenuhan dan stres ringan hingga menengah. Masalah psikologis selama ini ditangani melalui pemberian nasehat dengan niat dakwah untuk memberikan kesempatan kepada santri agar mau kembali dalam kondisi kestabilannya. Pendekatan yang dilakukan terkadang masih dianggap terlalu dogmatis sehingga belum menyentuh sisi-sisi psikologis dan afektif bagi santri. Selain itu, beberapa santri yang pernah ditemui mengaku selama ini hanya menyimpan seluruh permasalahan dirinya. Padahal ia mengaku membutuhkan sosok yang dapat menjadi tempat curhat yang dapat sekaligus menenangkannya. Beberapa santri mengaku tidak terlalu nyaman dengan cerita kepada seseorang yang umurnya 
terlampau jauh karena dianggap tidak mampu memahami permasalahan sesuai dengan kacamata usianya.

Gambaran kondisi lainnya adalah Pesantren ini membutuhkan lebih banyak sosok santri yang dapat memberikan inspirasi bagi santri lainnya melalui pendekatan yang lebih humanis sehingga akan tercipta hubungan yang lebih harmonis terutama antar santri. Melalui pelatihan dan pendampingan MPC atau Milennial Peer Counselor diharapkan akan tumbuh santri-santri yang memiliki kompetensi untuk memberikan layanan konsultasi dan konseling kepada santri-santri yang lainnya

Harapan, Target dan Kondisi yang diinginkan setelah selama dan setelah penyelenggaran kegiatan ini antara lain

1. Santri memiliki duta atau kader khusus yang dapat menjadi rujukan mereka dalam menyelesaikan masalah sehari-hari (Daily Problem) terutama yang bersifat psikologis;

2. Santri memperoleh wawasan tentang teknik komunikasi dan konseling yang dapat menjadi bekal mereka untuk mengamalkan ilmu ini kapanpun dan dimanapun;

3. Lembaga dapat melakukan pemetaan terhadap permasalahan psikologis santri sehingga data tersebut dapat digunakan untuk menciptakan program-program baru demi meningkatkan kualitas pembelajaran dan sosial di pesantren.;

4. Melalui Millenial Peer Counselor lembaga diharapkan mampu mendirikan biro khusus atau unit khusus berkaitan dengan berbagai layanan psikologis yang ditujukan untuk santri seperti Pusat Konseling Islam, Biro Layanan bimbingan dan konseling Islam dan sebagainya;

5. Lembaga mempunyai kesempatan yang lebih luas untuk mengembangkan santri dengan kompetensi tambahan kepada duta konselor sebaya milenial seperti kompetensi motivator muslim, instruktur muda, dan trainer pengembangan diri bagi sesama santri dan lingkungan sekitar pondok.

Seluruh kondisi yang diharapkan tersebut menjadi sebuah pemantik untuk mensukseskan penyelenggaraan program pendampingan MPC atau Milennial Peer Counselor di Lembaga Islam seperti Pondok Pesantren. Hal ini guna mewujudkan pesantren dengan santri milennial yang sehat mental menuju perkembangan diri yang optimal

Gambar 1. Kegiatan Pendampingan Milenial Peer Counselor (MPC)

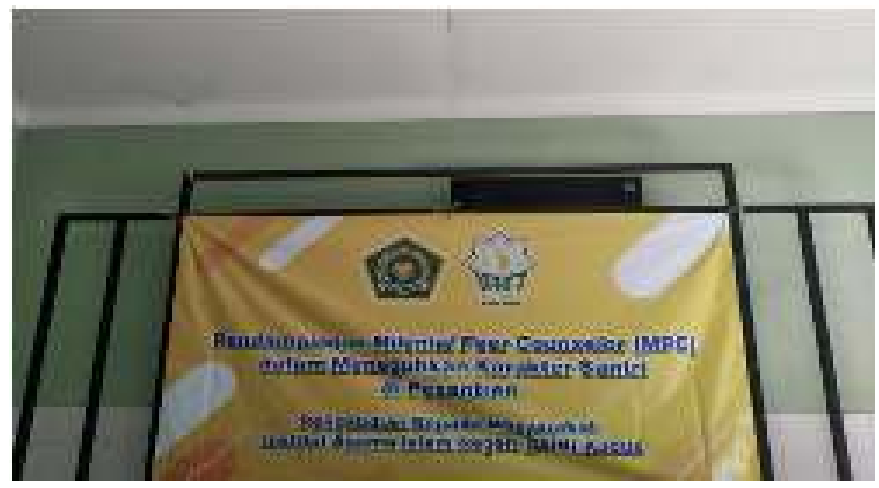

Selanjutnya, berkaitan dengan strategi pendekatan konseling Realita adalah seperti dalam uraian berikut. Salah satu hal yang dipertimbangkan dalam pemilihan pendekatan konseling adalah karaktersitik masalah konseli. Penanganan siswa yang 
mempunyai masalah tentang cinta dapat diselesaikan dengan bantuan pendekatan konseling Realitas. Setiap manusia mempunyai pilihan tentang apa yang akan dilakukan. Kebenaran subjektif dan memberikan reaksi terhadap dunia dari lokus evaluasi internal adalah bagian dari manusia (Palmer, 2013). Menurut konseling Realitas, masalah disebabkan oleh ketidakmampuan individu untuk membina hubungan dengan orang-orang yang ada di dalam hidupnya.

Manusia bertanggung jawab akan diri sendiri dalam pemenuhan kehidupan manusia. Menurut Glasser manusia mempunyai Lima kebutuhan dasar yakni: 1) kebutuhan bertahan hidup (survival), 2) mencintai dan dicintai (love and belonging), 3) kekuasaan atau prestasi (power or achievement), 4) kebebasan atau kemerdekaan (freedom or independence), dan kesenangan (fun). Dalam pemenuhan kebutuhan, manusia mempunyai prinsip 3R (Right, Reality, dan Responsibility). Kegagalan manusia memenuhi kebutuhan dasar yang sesuai dengan prinsip 3R akan menyebabkan manusia bermasalah. Begitu juga siswa, siswa adalah juga manusia yang mempunyai kebutuhan dasar. Dalam membantu siswa memenuhi kebutuhan dasar tersebut, maka konselor dapat melakukan konseling dengan pendekatan konseling Realita (Gaston \& American Counseling Association, n.d.).

Tahap konseling Realitas mengacu pada konsep dari Wubbolding (Corey, 2015) WDEP (Wants, Doing/Direction, Evaluation, dan Planning/Action). Konsep ini tergambar dalam langkah-langkah umum dari konseling Realitas. Berikut ini langkah-langkah dari konseling Realitas: 1) keterlibatan (Involvement), 2) mengidentifikasi perilaku sekarang (Here and Now), 3) mengevaluasi tingkah laku saat ini (Evaluation), 4) perencanaan tindakan baru (plan), 5) komitmen, 6) Pengakhiran dan terminasi (termination) (Cooper, Gordon, \& Rixon, n.d.). (1) Tahap pertama adalah keterlibatan. Konselor membangun keterlibatan dengan melakukan pembahasan topik netral. Pembahasan topik netral bertujuan untuk membangun keterlibatan konseli dalam proses konseling yang akan dilakukan. Konselor dalam proses konseling Realitas perlu menciptakan kehangatan (warmth), accepting, dan hubungan saling percaya antara konselor dan konseli. sikap dasar konselor dapat menjadi faktor terapeutik bagi kefektifan konseling (Palmer, 2013). (2) Tahap kedua adalah Mengidentifikasi perilaku sekarang (hereandnow). Tahap ini, konselor mengidentifikasi want dan do. Identifikasi want adalah menanyakan kepada konseli tentang keinginan, kebutuhan, persepsi, dan komitmen dari konseli. Sedangkan identifikasi do adalah kegiatan untuk mengidentifikasi tingkah laku atau tindakan yang dilakukan konseli untuk memenuhi want (Gaston \& American Counseling Association, n.d.); (3) Tahap ketiga adalah mengevaluasi tingkah laku saat ini (evaluation). Evaluation adalah kegiatan untuk membantu konseli untuk melakukan evaluasi diri dan membahas prinsip 3R (Right, Reality, dan Responsibility) (Palmer, 2013). Konselor mengajak konseli untuk mengevaluasi tingkah laku yang telah dilakukan konseli dalam rangka memenuhi kebutuhan; (4) Tahap keempat adalah perencaaan tindakan baru atau plan. Tahap ini merupakan kegiatan untuk membantu konseli membuat dan menyusun rencana-rencana dan pilihan-pilihan tingkah laku yang sesuai dengan prinsip 3R (Right, Reality, dan Responsibility) (Martin \& Wood, 1983); (5) Tahap kelima adalah komitmen. Komitmen dalam pendekatan konseling Realitas tidak hanya diucapkan secara verbal namun harus diwujudkan dalam sebuah tulisan tangan. Komitmen merupakan kontrak dan bukti tertulis tentang rencanarencana yang akan dilakukan konseli terkait dengan want. Komitmen tersebut 
ditandatangani oleh konselor dan konseli.; (6) Tahap keenam adalah terminasi. Tahap ini adalah untuk mengakhiri proses konseling. konseling dirasa selesai, apabila terjadi perubahan pada diri konseli. perubahan yang dapat dilihat adalah perubahan bagaimana cara konseli berpikir tentang masalah, kemampuan konseli untuk membuat rencana-rencana baru, serta adanya kemauan konseli melakukan rencana dan hal-hal yang telah diperoleh dari proses konseling.

\section{Gambar 2. Proses Pendampingan MPC}

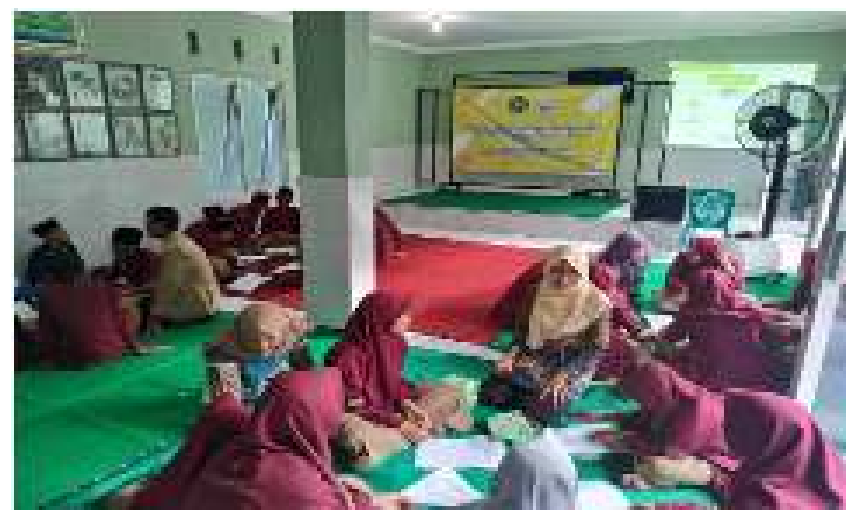

Gambar 3. Kebersamaan Tim Bersama Keluarga Besar Ponpes Nurul Jannah

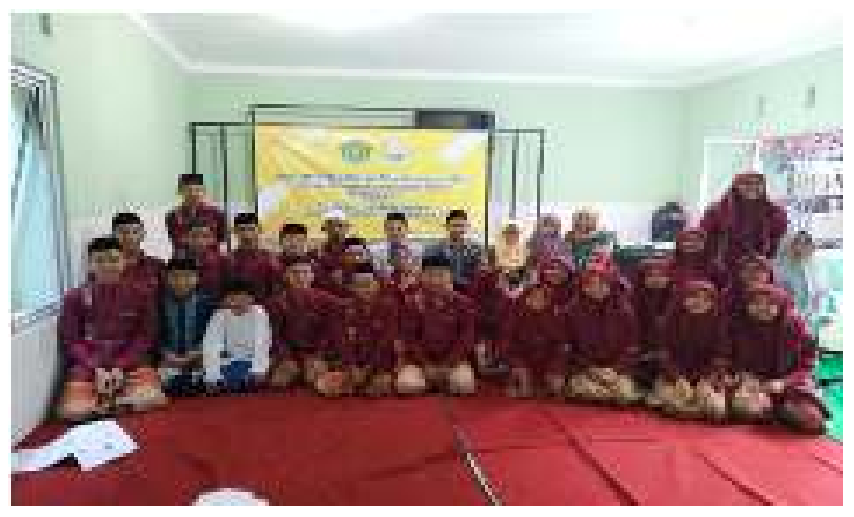

Berikut adalah gambaran kegiatan pendampingan Konselor Sebaya Milenial bagi Pesantren Pondok Pesantren Nurul Jannah Kudus yang diwujudkan dalam beberapa aktivitas yang telah dilakukan yakni (1) Membangun hubungan yang baik dengan ustadz dan ustadzah melalui koordinasi aktif untuk memetakan permasalahan santri secara makro dan mikro; (2) Diadakan asesmen singkat kepada santri terpilih untuk diberikan pendampingan sebagai calon duta Milennial Peer Counselor melalui pelatihan intensif dengan mengundang narasumber yang berkompeten di bidang layanan konseling sebaya; (3) santri diminta saling menjadi tutor sebaya dalam mengamati proses mikro konseling yang wajib dilaporkan tiap dua minggu; (4) santri atau peserta mengkampanyekan program layanan konseling sebaya bagi santri-santri lainnya; (5) menyusun program bersama antara tim, ustadz dan ustadzah serta duta Milennial Peer Counselor. 


\section{PENUTUP}

\section{Simpulan}

Setelah pemaparan kegiatan pengabdian di Pondok Pesantren Nurul Jannah Kudus maka dapat disimpulkan beberapa hal berikut. Pertama. Hasil pengabdian ini dapat dilaporkan dan dilanjutkan karena kegiatan berjalan dengan lancar dan sesuai dengan ekspektasi. Hal ini sesuai dengan beberapa aspek berkaitan dengan kondisi yang diharapkan atas terselenggaranya kegiatan ini. Harapan, Target dan Kondisi yang diinginkan setelah selama dan setelah penyelenggaran kegiatan ini antara lain (1) Santri memiliki duta atau kader khusus konselor sebaya yang dapat menjadi rujukan mereka dalam menyelesaikan masalah sehari-hari (Daily Problem) terutama yang bersifat psikologis; (2) Santri memperoleh wawasan tentang Teknik komunikasi dan konseling yang dapat menjadi bekal mereka untuk mengamalkan ilmu ini kapanpun dan dimanapun; (3) milenial peer counselor (MPC) menjadi salah satu tonggak pengembangan program psikologis bagi pesantren kedepannya. Kedua, Indikator keberhasilan dari program ini dapat dilihat dari beberapa faktor diantaranya (1) terpenuhinya target jumlah peserta (2) ke-komprehensif-an materi yang telah disampaikan dengan waktu yang terbatas (13.00-17.00) sudah mencakup teori dan praktik konseling serta praktik pemecahan masalah bagi para peserta; (3) sambutan yang baik dari Lembaga pondok pesantren; (4) dan respon peserta yang merasa sangat terbantu dengan adanya kegiatan ini (menurut hasil wawancara dengan beberapa peserta dan pengurus pondok pesantren). Ketiga, Program kegiatan pengabdian masyarakat berupa pendampingan konselor sebaya ini ternyata mampu menjadi salah satu faktor penting dalam penyelesaian masalah psikologis santri di pesantren yang mungkin jarang tersentuh karena "jarak" santri dengan para pengasuhnya.

\section{Saran dan Rekomendasi}

Program pengabdian kepada masyarakat berupa pendampingan millenial peer counselor (MPC) untuk meneguhkan karakter santri di pesantren Nurul Jannah menghasilkan beberapa rekomendasi antara lain (a) Lembaga dapat melakukan pemetaan terhadap permasalahan psikologis santri sehingga data tersebut dapat digunakan untuk menciptakan program-program baru demi meningkatkan kualitas pembelajaran dan sosial di pesantren; (b) Melalui Millenial Peer Counselor Lembaga diharapkan mampu mendirikan biro khusus atau unit khusus berkaitan dengan berbagai layanan psikologis yang ditujukan untuk santri seperti Pusat Konseling Islam, Biro Layanan konseling Islam dan sebagainya; (c) Lembaga mempunyai kesempatan yang lebih luas untuk mengembangkan santri dengan kompetensi tambahan kepada duta konselor sebaya milenial seperti kompetensi motivator muslim, instruktur muda, dan trainer pengembangan diri bagi sesame santri dan lingkungan sekitar pondok; (d) Program pelatihan dan pendampingan konselor sebaya patut mendapatkan perhatian dari pondok pesantren dan stakeholder demi terwujudnya situasi sehat mental bagi santri dan seluruh warga pondok. Maka dari itu, kelanjutan program ini perlu diimplementasikan secara lebih baik. 


\section{DAFTARPUSTAKA}

ABKIN. (2008). Penataan Pendidikan Profesional Konselor dan Layanan Bimbingan dan Konseling Dalam Jalur Pendidikan Formal. Jakarta: Depdiknas.

Azmi, K. R. (2018). Keterampilan Berpikir (Mind Skills) Pada Pros Konseling: Kajian Dalam Perkembangan Kognitif Neurosains. KONSELING EDUKASI" Journal of Guidance and Counseling", 2(1), 43-55.

Carter, S. P., \& Janzen, H. L. (1994). Peer Counseling or Peer Support-There is a Difference. Canadian Journal of School Psychology, 10(1), 36-42. https://doi.org/10.1177/082957359401000105

Cooper, B., Gordon, J., \& Rixon, A. (n.d.). Best practice with children and families : critical social work stories. Retrieved from https://www.google.com/search?safe=strict\&source=hp\&ei=EoykXN_UEIz6v gSelY7QDw\&q=Jones\%2C+R.N.+2003.+Basic + counseling + skills\%3A+A+H elper's+Manual. + London $\% 3 \mathrm{~A}+$ Sage + Publications\&btnK $=$ Google + Search\&oq $=$ Jones $\% 2 \mathrm{C}+$ R.N. $+2003 .+$ Basic + counseling + skills\%3A+A+Helper's + Manual. + London $\% 3 \mathrm{~A}+$ Sage + Publications\&gs_l=psyab.3...605717.620449..621581...0.0..3.1021.5420.0j6j14j7-1.....0....2j1..gwswiz.....0..0.IElJcdtwlok

Corey, G. (2015). Theory and practice of counseling and psychotherapy.

Fenti Hikmawati. (2015). Bimbingan dan Konseling Perspektif Islam. Jakarta: Rajawali Pers.

Gaston, B. E., \& American Counseling Association. (n.d.). The ACA encyclopedia of counseling.

Hotifah, Y. (2017). Peer Counseling in Perspective of Pesantren. Journal of Social Science (COES\&RJ-JSS), 6, 291-299.

Hurley, A., Pfadt, A., ... D. T.-M. of diagnosis and, \& 1996, undefined. (n.d.). Counseling and psychotherapy. Researchgate.Net. Retrieved from https://www.researchgate.net/profile/Anne_Hurley3/publication/285589544_Ps ychotherapy_and_counseling/links/5660971f08ae4931cd598b2a/Psychotherap y-and-counseling.pdf

M.H., G. R. L. \& M. (n.d.). Introduction to Counseling and Guidance. New York: MacMillan Publishing Company.

Martin, D., \& Wood, L. (1983). Counseling and therapy skills.

Palmer, L. K. (2013). Legitimizing and Reclaiming Master's Training and Education in Counseling Psychology. The Counseling Psychologist, 41(5), 700-709. https://doi.org/10.1177/0011000012473164 
Rahmi, E. M. (2001). Arah Baru Pendidikan Islam di Indonesia. Jakarta: Logos Wacana Ilmu.

Santoso, B. (2008). Dasar-Dasar Bimbingan dan Konseling. Malang: : UM Press.

Schmuller., M. \&. (n.d.). The Fundamentals of Counseling Program in School. New York, NY: Springe

Shertzer, Bruce \& Stone, S. C. (n.d.). Fudamentalso of Guidance. Fourth Edition. Boston: Houghton Mifflin Company.

Sukmadinata. (2012). Metode Penelitian dalam Pendidikan. Bandung: alfabeta. 